\title{
Modulation of human lymphocyte proliferation by salivary gland extracts of ixodid ticks (Acari: Ixodidae): effect of feeding stage and sex
}

\author{
Terézia Rolníková ${ }^{1}$, Mária Kazimírová ${ }^{1}$ and Milan Buc ${ }^{2}$ \\ ${ }^{1}$ Institute of Zoology, Slovak Academy of Sciences, Dúbravská cesta 9, SK-84506 Bratislava, Slovakia; \\ ${ }^{2}$ Institute of Immunology, School of Medicine, Comenius University, Sasinkova 4, SK-81108 Bratislava, Slovakia
}

Key words: ticks, salivary glands, human lymphocytes, Rhipicephalus appendiculatus, Ixodes ricinus, Amblyomma variegatum

\begin{abstract}
Ixodid ticks remain attached to their hosts for several days to weeks. During this extended feeding process new proteins involved in the modulation of host immune responses are expressed in tick salivary glands. In our study a stimulatory or inhibitory effect of salivary gland extracts (SGE) of unfed and partially fed female Ixodes ricinus (Linnaeus, 1758), female and male Amblyomma variegatum (Fabricius, 1794) and Rhipicephalus appendiculatus Neumann, 1901 ticks on human lymphocyte proliferation induced by Concanavalin A (ConA) and phytohaemagglutinin (PHA), respectively, was investigated. SGE of all female ticks examined suppressed proliferation of ConA-induced lymphocytes; highly significant suppression was observed in the presence of unfed I. ricinus and 9-day fed A. variegatum SGE. SGE of partially fed A. variegatum and I. ricinus females suppressed PHA responses of lymphocytes. Lymphocytes showed reduced PHA and ConA responses in the presence of SGE of unfed and 2-day fed $R$. appendiculatus females, while SGE of 6-day fed females enhanced PHA responses, but reduced their ConA responses; generally SGE of 2-day fed females displayed the strongest inhibition. Amblyomma variegatum male SGE slightly enhanced PHA, but significantly reduced ConA responses of lymphocytes and their inhibitory effect increased during feeding. SGE of unfed and 2-day fed R. appendiculatus males enhanced PHA and ConA responses and those of 6-day fed males suppressed lymphocyte proliferation. The results suggest that (i) species- and sex-specific differences exist in the effects of tick salivary gland antigens on human lymphocyte proliferation and (ii) effect of SGE on human lymphocyte responses to mitogens varies depending on the tick feeding status.
\end{abstract}

Ticks are obligate blood-feeding ectoparasites, with many species remaining attached to their hosts and acquiring a bloodmeal over a period ranging from days to weeks (Sonenshine 1991). The long contact between a tick and its host provides a host time to develop innate and adaptive host immune responses against the parasites. Not surprisingly, ticks have developed a number of countermeasures to evade the host immune response. Several genes are induced in tick salivary glands during the feeding process, leading to the expression of new proteins. These proteins are secreted into the tick saliva and are potentially involved in modulation of host immune and haemostatic responses. Tick saliva contains a large number of pharmacologically active molecules that possess antihaemostatic, vasoactive and immunosuppressive properties (Ribeiro 1995a, b, Wikel and Bergman 1997, Ribeiro and Francischetti 2003). Consequently, modulation of the host immune response facilitates both tick feeding and transmission of various tick-borne pathogens (Wikel and Alarcon-Chaidez 2001).

The effect of salivary gland extracts (SGE) or saliva of different tick species has been mainly demonstrated in laboratory models (e.g., mouse, rabbit, guinea pig), however, that on human immune cells has been limited to in vitro studies. The inhibitory effect of tick SGE on NK cells (Kubeš et al. 1994, 2002, Kopecký and Kuthejlová 1998) and on the production of nitric oxide by macrophages (Kuthejlová et al. 2001) were reported. An IL-2 binding protein was identified in the saliva of the Lyme disease vector, Ixodes scapularis (Gillespie et al. 2001). The anti-chemokine activity of SGE from the ixodid ticks Amblyomma variegatum, Dermacentor reticulatus and Rhipicephalus appendiculatus was demonstrated by Hajnická et al. (2001) and Kocáková et al. (2002). It was also reported that ticks suppressed production of macrophage proinflammatory cytokines as well as secretion of $T_{H} 1$ cytokines, however, the synthesis of $\mathrm{T}_{\mathrm{H}} 2$ cytokines was up-regulated, indicating $\mathrm{T}_{\mathrm{H}} 2$ polarisation of the immune response (Fuchsberger et al. 1995, Ferreira and Silva 1999, Kováŕ et al. 2001, 2002, Leboulle et al. 2002). The tick-induced suppression of the host immune defences is also characterized by reduced ability of murine and human lymphocytes to proliferate in vitro in the presence of T-lymphocyte mitogens (Kováŕ et al. 2001, Leboulle et al. 2002).

There are only a few reports on changes of the immunomodulatory effects of tick saliva during their 
feeding (e.g., Kubeš et al. 2000, 2002, Bior et al. 2002, Rolníková et al. 2002). In the present study, the effects of SGE derived from male and female Amblyomma variegatum (Fabricius, 1794), Rhipicephalus appendiculatus Neumann, 1901 and female Ixodes ricinus (Linnaeus, 1758) ticks on in vitro proliferation of human peripheral T-lymphocytes were compared and changes in lymphocyte responses to SGE of unfed and feeding ticks were investigated.

\section{MATERIALS AND METHODS}

\section{Ticks and tick salivary gland extracts (SGE)}

Adult $I$. ricinus were collected by flagging the vegetation in selected localities of south-western Slovakia known to be free of tick-borne encephalitis virus. Their salivary gland homogenates were screened for Borrelia burgdorferi by PCR and only negative samples were used in subsequent assays. Rhipicephalus appendiculatus and A. variegatum were obtained from laboratory colonies maintained at the Institute of Zoology of the Slovak Academy of Sciences. Salivary glands were dissected from unfed adult ticks or ticks that were allowed to feed in groups within retaining cells attached to the backs of laboratory animals. Females of I. ricinus were fed on laboratory mice for 2 or 5 days, females and males of $R$. appendiculatus were fed on guinea pigs for 2 or 6 days. Adult $A$. variegatum were fed on California rabbits for 2 or 9 days; hosts were always exposed to males for 4 days before females were added.

Ticks were gently removed from laboratory animals at different stages of feeding. Both removed and unfed ticks were washed in water, rinsed quickly in $70 \%$ ethanol and subsequently in distilled water. Their salivary glands were dissected under chilled $0.15 \mathrm{M} \mathrm{NaCl}$, washed twice with 0.15 $\mathrm{M} \mathrm{NaCl}$ and pooled in eppendorf tubes (10-50 SG pairs/50 $\mu 1$ $0.15 \mathrm{M} \mathrm{NaCl}$, depending on tick species, sex and feeding stage) and immediately frozen at $-70^{\circ} \mathrm{C}$ until required. Prior to the assays, batches of salivary glands were quickly thawed, homogenized using a pestle and centrifuged at $12,000 \mathrm{~g}$ for 10 min. Supernatants were removed, pellets resuspended in 0.15 $\mathrm{M} \mathrm{NaCl}$ and re-centrifuged. Supernatants obtained (SGE) were pooled and the protein concentration of the SGE was determined using the Bradford assay (Bradford 1976). SGE were diluted in $10 \%$ RPMI 1640 medium at concentrations 0.1 $\mu \mathrm{g}, 0.5 \mu \mathrm{g}$ and $1.0 \mu \mathrm{g}$ soluble protein $/ 50 \mu \mathrm{l}$ medium.

\section{Cell culture}

Blood was obtained from healthy human donors. Lymphocytes were isolated from heparinized venous blood by separation on a Ficoll-Verografin gradient (specific gravity 1.078 centrifugation at $440 \mathrm{~g}$ for $30 \mathrm{~min}$ at room temperature). Lymphocytes from the interface were removed, washed three times in balanced saline solution and resuspended $\left(10^{6}\right.$ cells $/ \mathrm{ml}$ ) in RPMI 1640 medium supplemented with $2 \mathrm{mM} \mathrm{L-}$ glutamine, $100 \mathrm{U} / \mathrm{ml}$ penicillin, $100 \mu \mathrm{g} / \mathrm{ml}$ streptomycin, $10 \mu \mathrm{g} / \mathrm{ml}$ gentamicin, and $10 \%$ heat-inactivated human serum. Lymphocyte suspensions $(100 \mu \mathrm{l} / \mathrm{well})$ were distributed to flat-bottom 96-well plates (TC Microwell 96, NUNC).

\section{Lymphocyte proliferation assay (LPA)}

To each well of the 96-well plate containing lymphocyte suspension either $50 \mu \mathrm{l}$ of RPMI medium (non-stimulated cells) or $50 \mu \mathrm{l}$ of Concanavalin A (ConA, Sigma; $1 \mu \mathrm{g} / 50 \mu \mathrm{l}$ RPMI) or phytohaemagglutinin (PHA, Sigma; $5 \mu \mathrm{g} / 50 \mu \mathrm{l}$ RPMI) and $50 \mu \mathrm{l} \mathrm{SGE} \mathrm{(containing} 0.1 \mu \mathrm{g}, 0.5 \mu \mathrm{g}$ or $1.0 \mu \mathrm{g}$ soluble protein $/ 50 \mu \mathrm{RPMI}$, respectively) were added. Mitogens were added simultaneously with SGE. Lymphocyte cultures were incubated for $66 \mathrm{~h}$ at $37^{\circ} \mathrm{C}$ in $5 \% \mathrm{CO}_{2}$. To measure cell proliferation, $37 \mathrm{~Bq}$ of tritiated thymidine (Amersham) $\left(\left[{ }^{3} \mathrm{H}\right] \mathrm{TdR}\right) / 20 \mu 1$ 10\% RPMI 1640) were added to each well $6 \mathrm{~h}$ before cell harvest. The cells were harvested on glass fibre filters (Whatman) using an automatic cell harvester (Auto-Mash, Dynex). The amount of incorporated $\left[{ }^{3} \mathrm{H}\right] \mathrm{TdR}$ into DNA of proliferating lymphocytes was determined by liquid scintillation counting on a beta counter (Spectral, LKB). All samples were tested in triplicate and each assay was repeated 6-8 times, using blood from different donors. Mean disintegrations per minute (DPM) were determined for each sample. Absolute values measured for individual donors were transformed to relative values and are expressed as percentage of inhibition/stimulation of cell proliferation as compared to control lymphocytes (without addition of SGE). The percentage of stimulation/inhibition was calculated as follows:

Percentage of stimulation/inhibition of cells without addition of mitogens $(\mathrm{S} / \mathrm{I})$ :

$$
S(I)=\frac{S G E-\text { Control DPM }}{\text { Control DPM }} \cdot 100
$$

Percentage of stimulation/inhibition of cells with addition of mitogens $\left(\mathrm{S}_{\mathrm{M}} / \mathrm{I}_{\mathrm{M}}\right)$ :

$$
S(I)=\frac{S G E-\text { mitogens DPM }}{\text { mitogens } D P M} \cdot 100
$$

\section{Statistical analysis}

The effects of tick feeding stage and SGE concentrations on lymphocyte proliferation were evaluated using one-way analysis of variance (ANOVA), followed by the Bonferroni test for pair-wise comparisons. Responses of lymphocytes to SGE of male and female ticks of the same species and feeding stage were compared by two-sample analysis ( $t$-test). For statistical analyses, percentages were transformed to arcsine $\sqrt{p}$ to meet the criteria of parametric statistical tests. In all statistical analyses, $P \leq 0.05$ was considered significant.

\section{RESULTS}

The in-vitro proliferative responses of human lymphocytes were significantly affected by exposure to tick salivary gland extracts. Different patterns of inhibition or enhancement of proliferation were observed for non-stimulated and mitogen-stimulated lymphocytes treated with SGE of the three tick species. For each tick species, lymphocyte responses also varied when cultured with SGE of females and males as well as with SGE of unfed and partially engorged individuals.

Responses of lymphocytes to tick SGE were generally dose-dependent, however, for most of the treatments the differences in percentage of stimulation/ inhibition of proliferation of cells exposed to $0.1,0.5$ and 1.0 $\mu \mathrm{g}$ SGE soluble proteins were not statistically significant (Tables 1-3). Consequently, responses of 
Table 1. Stimulation/inhibition of human lymphocyte proliferation (\% change compared with controls) in cultures treated with various concentrations of female Ixodes ricinus salivary gland extracts (SGE), without mitogens and induced by phytohaemagglutinin (PHA) and Concanavalin A (ConA).

\begin{tabular}{|c|c|c|c|c|c|cc|c|}
\hline $\begin{array}{c}\text { Tick feeding } \\
\text { stage }\end{array}$ & $\begin{array}{c}\text { Treatment } \\
\text { SGE proteins } \\
(\mu \mathrm{g} / \text { well) }\end{array}$ & \multicolumn{2}{|c|}{$\begin{array}{c}\text { No mitogens } \\
\text { (\% change) }\end{array}$} & \multicolumn{3}{|c|}{$\begin{array}{c}\text { PHA } \\
\text { (\% change) }\end{array}$} & \multicolumn{3}{|c|}{$\begin{array}{c}\text { ConA } \\
\text { (\% change) }\end{array}$} \\
\hline \multirow{2}{*}{ Unfed } & 0.1 & 5 & $-44.4(6.0)^{\mathrm{a}}$ & 8 & $-24.1(3.2)^{\mathrm{a}}$ & 8 & $-33.8(4.2)^{\mathrm{a}}$ \\
& 0.5 & 5 & $-38.7(8.4)^{\mathrm{a}}$ & 8 & $-47.1(3.6)^{\mathrm{b}}$ & 8 & $-45.4(6.9)^{\mathrm{a}}$ \\
& 1.0 & 4 & $-31.3(8.3)^{\mathrm{a}}$ & 8 & $-57.9(2.8)^{\mathrm{b}}$ & 8 & $-63.0(3.0)^{\mathrm{a}}$ \\
\hline \multirow{2}{*}{ Day 2 } & 0.1 & 5 & $56.9(22.4)^{\mathrm{a}}$ & 6 & $-4.9(7.3)^{\mathrm{a}}$ & 5 & $-6.8(4.5)^{\mathrm{a}}$ \\
& 0.5 & 5 & $58.8(9.6)^{\mathrm{a}}$ & 6 & $-16.6(7.9)^{\mathrm{a}}$ & 5 & $-35.4(6.6)^{\mathrm{b}}$ \\
& 1.0 & 5 & $35.6(13.8)^{\mathrm{a}}$ & 6 & $-13.8(6.3)^{\mathrm{a}}$ & 5 & $-25.2(7.3)^{\mathrm{ab}}$ \\
\hline \multirow{3}{*}{ Day 5 } & 0.1 & 8 & $58.4(12.2)^{\mathrm{a}}$ & 8 & $-31.0(4.2)^{\mathrm{a}}$ & 8 & $-10.5(3.8)^{\mathrm{a}}$ \\
& 0.5 & 8 & $26.8(6.6)^{\mathrm{a}}$ & 7 & $-33.4(7.3)^{\mathrm{a}}$ & 8 & $-9.0(4.4)^{\mathrm{a}}$ \\
& 1.0 & 7 & $30.9(12.6)^{\mathrm{a}}$ & 8 & $-44.3(5.5)^{\mathrm{a}}$ & 8 & $-17.3(3.9)^{\mathrm{a}}$ \\
\hline
\end{tabular}

$\mathrm{n}$ - numbers of replicates in treatments; means indicated by the same superscripts between SGE concentrations for each treatment are not significantly different (one-way ANOVA followed by Bonferroni test, $\mathrm{P} \leq 0.05$ ).

Table 2. Stimulation/inhibition of human lymphocyte proliferation (\% change compared with controls) in cultures treated with various concentrations of female and male Rhipicephalus appendiculatus salivary gland extracts (SGE), without mitogens and induced by phytohaemagglutinin (PHA) and Concanavalin A (ConA).

\begin{tabular}{|c|c|c|c|c|c|c|c|}
\hline \multirow{2}{*}{$\begin{array}{l}\text { Tick feeding } \\
\text { stage }\end{array}$} & \multirow{2}{*}{$\begin{array}{c}\text { Treatment } \\
\text { SGE proteins } \\
\text { ( } \mu \mathrm{g} / \text { well })\end{array}$} & \multicolumn{2}{|c|}{$\begin{array}{l}\text { No mitogens } \\
\text { (\% change) }\end{array}$} & \multicolumn{2}{|c|}{$\begin{array}{c}\text { PHA } \\
(\% \text { change })\end{array}$} & \multicolumn{2}{|c|}{$\begin{array}{c}\text { Con } A \\
(\% \text { change })\end{array}$} \\
\hline & & $\mathrm{n}$ & Mean (S.E.) & $\mathrm{n}$ & Mean (S.E.) & $\mathrm{n}$ & Mean (S.E.) \\
\hline Females & 0.1 & 5 & $-10.9(4.7)^{\mathrm{a}}$ & 8 & $-19.5(3.5)^{\mathrm{a}}$ & 8 & $-16.0 \quad(5.9)^{\mathrm{a}}$ \\
\hline \multirow[t]{2}{*}{ Unfed } & 0.5 & 7 & $-17.4(7.5)^{\mathrm{a}}$ & 7 & $-18.2(8.3)^{\mathrm{a}}$ & 8 & $-31.3(5.9)^{\mathrm{ab}}$ \\
\hline & 1 & 6 & $-26.2(7.8)^{\mathrm{a}}$ & 6 & $-22.9(7.3)^{\mathrm{a}}$ & 8 & $-41.4(5.7)^{b}$ \\
\hline Females & 0.1 & 6 & $-29.2(9.2)^{\mathrm{a}}$ & 8 & $-45.9(7.7)^{\mathrm{a}}$ & 8 & $-51.2(4.0)^{\mathrm{a}}$ \\
\hline \multirow[t]{2}{*}{ Day 2} & 0.5 & 7 & $-29.2 \quad(9.2)^{\mathrm{a}}$ & 7 & $-45.9(7.7)^{\mathrm{a}}$ & 7 & $-51.2(4.0)^{\mathrm{a}}$ \\
\hline & 1 & 8 & $-36.6(6.6)^{\mathrm{a}}$ & 6 & $-48.7(7.0)^{\mathrm{a}}$ & 8 & $-41.9(8.0)^{\mathrm{a}}$ \\
\hline Females & 0.1 & 6 & $-13.6(4.7)^{\mathrm{a}}$ & 7 & $-15.6(6.0)^{\mathrm{a}}$ & 8 & $-17.5(2.0)^{\mathrm{a}}$ \\
\hline \multirow[t]{2}{*}{ Day 6} & 0.5 & 6 & $-20.4(6.4)^{\mathrm{ab}}$ & 8 & $19.4(4.8)^{\mathrm{b}}$ & 7 & $-10.4(4.3)^{a}$ \\
\hline & 1 & 8 & $-42.3(7.3)^{b}$ & 7 & $32.3(10.3)^{b}$ & 8 & $-15.6(5.5)^{\mathrm{a}}$ \\
\hline Males & 0.1 & 6 & $6.8(7.0)^{\mathrm{a}}$ & 6 & $29.1(12.7)^{\mathrm{a}}$ & 4 & $23.4(3.1)^{\mathrm{a}}$ \\
\hline \multirow[t]{2}{*}{ Unfed } & 0.5 & 6 & $-6.2(4.5)^{a}$ & 5 & $41.5(16.1)^{\mathrm{a}}$ & 5 & $26.9(19.1)^{\mathrm{a}}$ \\
\hline & 1 & 6 & $-14.5(9.4)^{\mathrm{a}}$ & 5 & $46.1(19.4)^{\mathrm{a}}$ & 5 & $25.2(11.3)^{\mathrm{a}}$ \\
\hline Males & 0.1 & 8 & $33.7(7.1)^{\mathrm{a}}$ & 6 & $36.0(8.0)^{\mathrm{a}}$ & 7 & $28.9(6.7)^{\mathrm{a}}$ \\
\hline \multirow[t]{2}{*}{ Day 2} & 0.5 & 8 & $103.0(21.1)^{b}$ & 8 & $14.6(4.8)^{\mathrm{a}}$ & 6 & $30.8(4.8)^{\mathrm{a}}$ \\
\hline & 1 & 7 & $94.5(31.8)^{b}$ & 5 & $40.7(6.1)^{\mathrm{a}}$ & 8 & $36.7(11.4)^{\mathrm{a}}$ \\
\hline Males & 0.1 & 7 & $-11.8(7.4)^{\mathrm{a}}$ & 8 & $-26.5(6.0)^{\mathrm{a}}$ & 8 & $-28.3(6.1)^{\mathrm{a}}$ \\
\hline \multirow[t]{2}{*}{ Day 6} & 0.5 & 6 & $-12.7 \quad(6.4)^{\mathrm{a}}$ & 8 & $-21.9(5.6)^{\mathrm{a}}$ & 8 & $-20.9(6.4)^{\mathrm{a}}$ \\
\hline & 1 & 8 & $6.8(7.0)^{\mathrm{a}}$ & 7 & $-13.9(4.2)^{\mathrm{a}}$ & 7 & $-27.7(7.6)^{a}$ \\
\hline
\end{tabular}

$\mathrm{n}$ - numbers of replicates in treatments; means indicated by the same superscripts between SGE concentrations for each treatment are not significantly different (one-way ANOVA followed by Bonferroni test, $\mathrm{P} \leq 0.05$ ).

lymphocytes to SGE of the three tick species and sexes and to SGE from various feeding stages were further evaluated only for the dose $1.0 \mu \mathrm{g}$.

Responses of non-stimulated lymphocytes to SGE of unfed I. ricinus females were suppressed, but they were enhanced by SGE of partially engorged ticks (Fig. 1). In contrast, no significant differences between responses of non-stimulated cells were found when treated with SGE of unfed and partially fed $R$. appendiculatus females (Fig. 2) and A. variegatum males (Fig. 3). SGE derived from unfed and 6-day fed $R$. appendiculatus males suppressed cell proliferation, however, SGE of 2-day fed males had a $94.5 \%$ stimulatory effect. Consequently, differences between the effect of SGE of 2-day fed male and female $R$. appendiculatus were highly significant (Fig. 2). SGE of female $A$. variegatum suppressed cell proliferation and this effect significantly increased with feeding, but, except unfed ticks, the differences between sexes were not significant (Fig. 3).

Responses of lymphocytes induced by mitogens were suppressed by all feeding stages of I. ricinus, but SGE of unfed ticks had the strongest effect (Fig. 1). In majority of treatments, responses of mitogen-stimulated lymphocytes to male and female SGE of the same 
Table 3. Stimulation/inhibition of human lymphocyte proliferation (\% change compared with controls) in cultures treated with various concentrations of female and male Amblyomma variegatum salivary gland extracts (SGE), without mitogens and induced by phytohaemagglutinin (PHA) and Concanavalin A (ConA).

\begin{tabular}{|c|c|c|c|c|c|c|c|}
\hline \multirow{2}{*}{$\begin{array}{l}\text { Tick feeding } \\
\text { stage }\end{array}$} & \multirow{2}{*}{$\begin{array}{c}\text { Treatment } \\
\text { SGE proteins } \\
(\mu \mathrm{g} / \text { well })\end{array}$} & \multicolumn{2}{|c|}{$\begin{array}{l}\text { No mitogens } \\
\text { (\% change) }\end{array}$} & \multicolumn{2}{|r|}{$\begin{array}{c}\text { PHA } \\
(\% \text { change })\end{array}$} & \multicolumn{2}{|r|}{$\begin{array}{c}\text { ConA } \\
(\% \text { change })\end{array}$} \\
\hline & & $\mathrm{n}$ & Mean (S.E.) & $\mathrm{n}$ & Mean (S.E.) & $\mathrm{n}$ & Mean (S.E.) \\
\hline Females & 0.1 & 6 & $17.9 \quad(6.9)^{\mathrm{a}}$ & 8 & $69.2(5.5)^{\mathrm{a}}$ & 8 & $40.1 \quad(9.8)^{\mathrm{a}}$ \\
\hline \multirow[t]{2}{*}{ Unfed } & 0.5 & 5 & $8.0(10.3)^{\mathrm{a}}$ & 8 & $109.1(11.3)^{b}$ & 8 & $23.5(10.5)^{\mathrm{a}}$ \\
\hline & 1 & 5 & $4.1(17.6)^{\mathrm{a}}$ & 8 & $79.0(7.9)^{\mathrm{ab}}$ & 6 & $20.6 \quad(6.7)^{\mathrm{a}}$ \\
\hline Females & 0.1 & 6 & $21.2(10.7)^{\mathrm{a}}$ & 8 & $19.5 \quad(5.7)^{\mathrm{a}}$ & 7 & $-10.8 \quad(4.4)^{\mathrm{a}}$ \\
\hline \multirow[t]{2}{*}{ Day 2} & 0.5 & 7 & $-14.5 \quad(4.3)^{b}$ & 7 & $(5.3)^{\mathrm{a}}$ & 7 & -21.0 \\
\hline & 1 & 8 & $-17.2 \quad(5.5)^{\mathrm{b}}$ & 8 & $(4.8)^{\mathrm{a}}$ & 8 & $-17.3 \quad(6.3)^{\mathrm{a}}$ \\
\hline Females & 0.1 & 7 & $(4.8)^{\mathrm{a}}$ & 6 & $(6.9)^{\mathrm{a}}$ & 6 & -24.7 \\
\hline \multirow[t]{2}{*}{ Day 9} & 0.5 & 7 & $-3.9 \quad(1.9)^{\mathrm{a}}$ & 8 & $-53.7(7.3)^{b}$ & 7 & -46.5 \\
\hline & 1 & 6 & $-35.5(8.2)^{b}$ & 8 & $-57.5(7.5)^{b}$ & 7 & $-48.9 \quad(8.4)^{\mathrm{a}}$ \\
\hline Males & 0.1 & 8 & $-35.3(5.4)^{\mathrm{a}}$ & 7 & $19.1(5.0)^{\mathrm{a}}$ & 8 & $-14.9 \quad(5.3)^{\mathrm{a}}$ \\
\hline \multirow[t]{2}{*}{ Unfed } & 0.5 & 8 & $-37.4(5.1)^{\mathrm{a}}$ & 7 & $15.4(2.9)^{\mathrm{a}}$ & 8 & $-22.1 \quad(6.1)^{\mathrm{a}}$ \\
\hline & 1 & 8 & $-47.0(8.4)^{a}$ & 8 & $23.1(5.2)^{\mathrm{a}}$ & 7 & $-26.7(3.9)^{\mathrm{a}}$ \\
\hline Males & 0.1 & 8 & $6.5(6.6)^{\mathrm{a}}$ & 7 & $-31.7(5.6)^{\mathrm{a}}$ & 8 & $-26.6(4.8)^{\mathrm{a}}$ \\
\hline \multirow[t]{2}{*}{ Day 2} & 0.5 & 8 & $8.5(6.4)^{\mathrm{a}}$ & 7 & $-13.4(6.2)^{\mathrm{ab}}$ & 8 & $-40.4(4.1)^{\mathrm{ab}}$ \\
\hline & 1 & 4 & $-16.9(7.4)^{b}$ & 6 & $-0.03(8.5)^{b}$ & 8 & $-43.4(3.9)^{b}$ \\
\hline Males & 0.1 & 5 & $3.5(2.1)^{\mathrm{a}}$ & 8 & $4.5(2.3)^{\mathrm{a}}$ & 8 & $-34.2(4.1)^{\mathrm{a}}$ \\
\hline \multirow[t]{2}{*}{ Day 9} & 0.5 & 7 & $-7.4(3.1)^{\mathrm{b}}$ & 8 & $7.7(3.0)^{\mathrm{a}}$ & 8 & $-59.8(2.9)^{b}$ \\
\hline & 1 & 7 & $-26.9(7.8)^{b}$ & 8 & $3.6(7.5)^{\mathrm{a}}$ & 8 & $-67.9(3.5)^{b}$ \\
\hline
\end{tabular}

$\mathrm{n}$ - numbers of replicates in treatments; means indicated by the same superscripts between SGE concentrations for each treatment are not significantly different (one-way ANOVA followed by Bonferroni test, $\mathrm{P} \leq 0.05$ ).

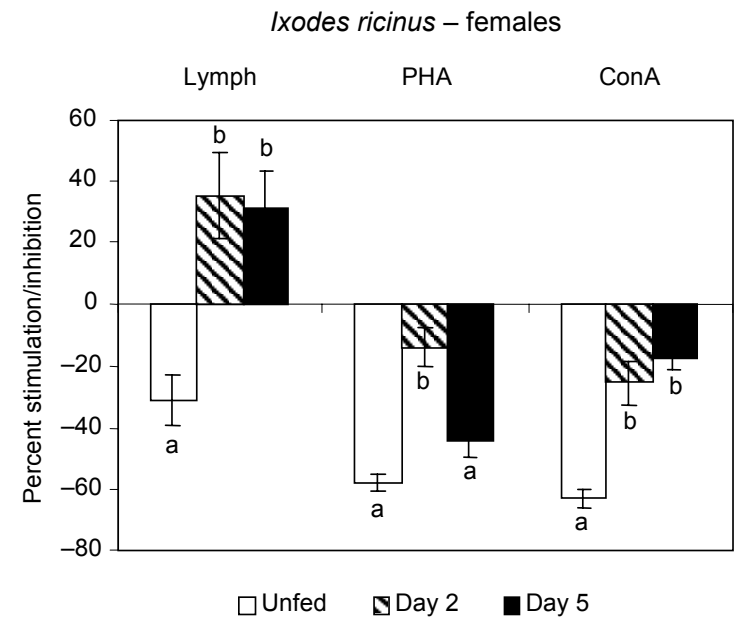

Fig. 1. Proliferation of human lymphocytes (\% change compared with control lymphocytes) after treatment with $1 \mu \mathrm{g}$ of SGE proteins of unfed and partially fed Ixodes ricinus females. Lymphocytes were non-stimulated with mitogens (Lymph) or stimulated with PHA and ConA. Values represent means \pm SEM. Means within a treatment indicated by the same letters are not significantly different (one-way ANOVA followed by Bonferroni test, $\mathrm{P} \leq 0.05)$. Results of ANOVA: non-stimulated lymphocytes $(\mathrm{F}=12.79, \mathrm{P}<0.001)$; lymphocytes stimulated with PHA $(\mathrm{F}=$ $30.50, \mathrm{P}<0.001)$; lymphocytes stimulated with $\mathrm{ConA}(\mathrm{F}=20.62$, $\mathrm{P}<0.001)$.

species significantly differed within a feeding status (Figs. 2, 3). Proliferative responses of mitogen-induced lymphocytes to SGE of $R$. appendiculatus also differed between the two mitogens applied (Fig. 2). While pro- liferation of Con-A-induced lymphocytes was suppressed by $R$. appendiculatus female SGE, proliferation of PHA-induced lymphocytes was suppressed only by 2-day fed females. SGE of unfed and 2-day fed males had a stimulatory effect on mitogen-induced proliferation, and only 6-day fed males suppressed proliferation.

Responses of mitogen-induced lymphocytes to $A$. variegatum SGE also varied with feeding stage and sex (Fig. 3). Proliferation of lymphocytes was enhanced when treated with SGE of unfed and 2-day fed females, but it was suppressed by SGE of 9-day fed females. The suppressive effect of male $A$. variegatum SGE on ConA-stimulated proliferation significantly increased with duration of feeding, however, this effect was not observed in PHA-stimulated lymphocytes.

\section{DISCUSSION}

Ticks have evolved various strategies to evade the immune response of hosts they feed on. Biologically active compounds in their salivary glands play the main role in immunosuppression and immunomodulation. Tick-induced immunosuppression of the host is characterized by decreased primary antibody responses to T-cell-dependent antigens, decreased production of $\mathrm{T}_{\mathrm{H}} 1$ cytokines (IL-2, IFN- $\gamma$ ) and enhanced production of $\mathrm{T}_{\mathrm{H}} 2$ cytokines (IL-4, IL-5, IL-6, IL-10, IL-13) (Willadsen and Jongejan 1999, Gillespie et al. 2000, Schoeler and Wikel 2001, Wikel and Alarcon-Chaidez 2001, Ribeiro and Francischetti 2003). 

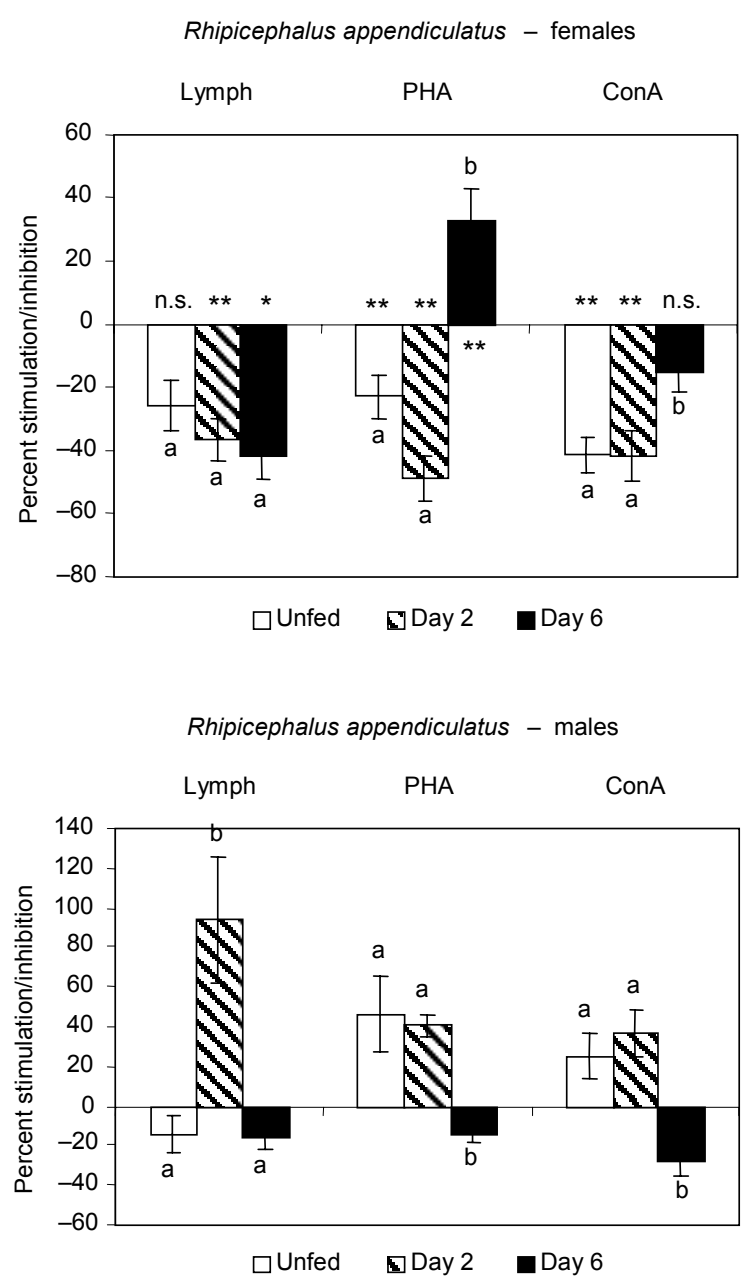

Fig. 2. Proliferation of human lymphocytes (\% change compared with control lymphocytes) after treatment with $1 \mu \mathrm{g}$ of SGE proteins of unfed and partially fed $R$. appendiculatus females and males. Lymphocytes were non-stimulated with mitogens (Lymph) or stimulated with PHA and ConA. Values represent means \pm SEM. Means within a treatment indicated by the same letters are not significantly different (one-way ANOVA followed by Bonferroni test, $\mathrm{P} \leq 0.05$ ). Results of ANOVA for female ticks: non-stimulated lymphocytes $(\mathrm{F}=$ 1.31 , n.s.); lymphocytes stimulated with PHA ( $\mathrm{F}=26.00, \mathrm{P}<$ $0.001)$; lymphocytes stimulated with ConA $(\mathrm{F}=5.67, \mathrm{P}<$ 0.05). Results of ANOVA for male ticks: non-stimulated lymphocytes $(\mathrm{F}=12.05, \mathrm{P}<0.001)$; lymphocytes stimulated with PHA $(\mathrm{F}=19.13, \mathrm{P}<0.001)$; lymphocytes stimulated with ConA $(\mathrm{F}=21.65, \mathrm{P}<0.001)$. Differences between responses to male and female SGE are indicated above or below the values for females as n.s. (not significant), $* \mathrm{P}<0.05$ or $* *$ $\mathrm{P}<0.01$ ( $t$-test)

Inhibition of T-cell responsiveness to ConA could result from the direct effect of salivary gland proteins on lymphocytes or from their production of IL-10 (Wikel 1999, Schoeler and Wikel 2001, Wikel and AlarconChaidez 2001). The suppression of T-lymphocyte proliferation can also be due to prostaglandin $E_{2}$ which
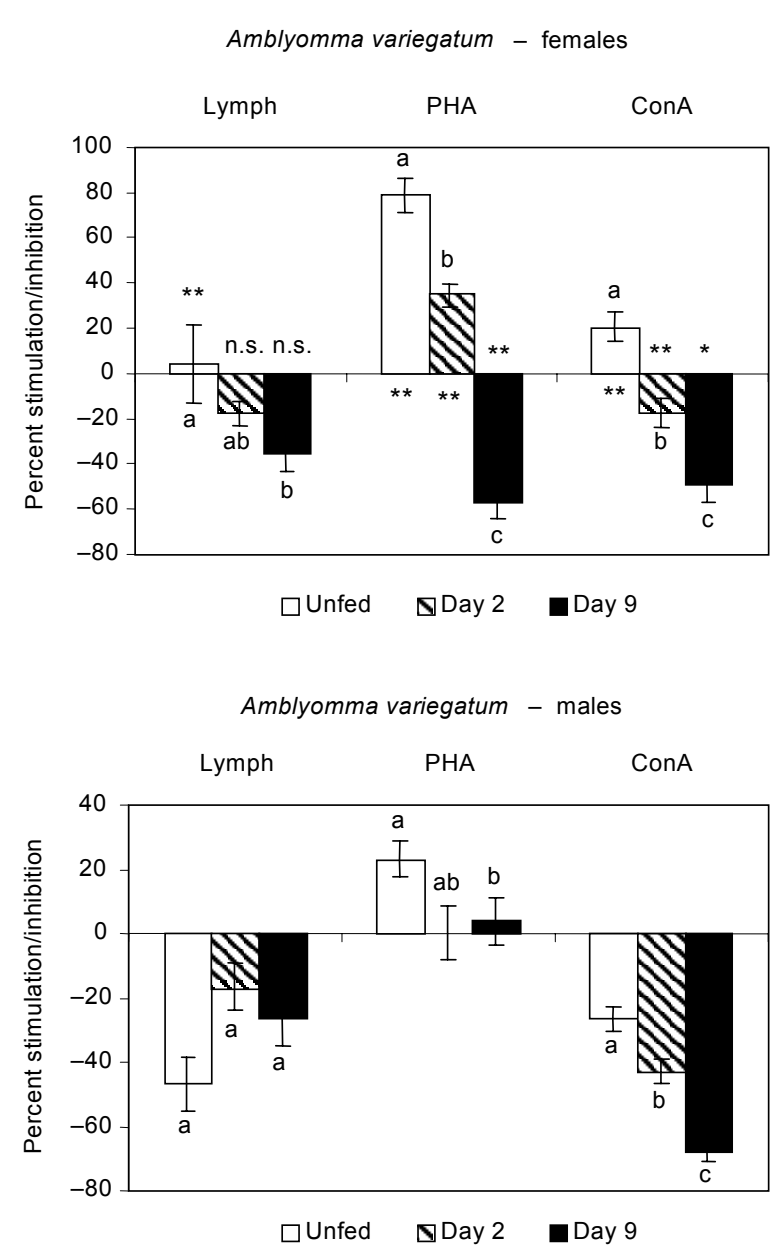

Fig. 3. Proliferation of human lymphocytes (\% change compared with control lymphocytes) after treatment with $1 \mu \mathrm{g}$ of SGE proteins of unfed and partially fed A. variegatum females and males. Lymphocytes were non-stimulated with mitogens (Lymph) or stimulated with PHA and ConA. Values represent means \pm SEM. Means within a treatment indicated by the same letters are not significantly different (one-way ANOVA followed by Bonferroni test, $\mathrm{P} \leq 0.05$ ). Results of ANOVA for female ticks: non-stimulated lymphocytes ( $\mathrm{F}=$ 78.04, $\mathrm{P}<0.001)$; lymphocytes stimulated with PHA ( $\mathrm{F}=$ $125.32, \mathrm{P}<0.001)$; lymphocytes stimulated with ConA ( $\mathrm{F}=$ 39.26, $\mathrm{P}<0.001)$. Results of ANOVA for male ticks: nonstimulated lymphocytes $(\mathrm{F}=3.08$, n.s.); lymphocytes stimulated with PHA $(\mathrm{F}=4.04, \mathrm{P}<0.05)$; lymphocytes stimulated with ConA $(\mathrm{F}=33.48, \mathrm{P}<0.001)$. Differences between responses to male and female SGE are indicated above or below the values for females as n.s. (not significant), $* \mathrm{P}<0.05$ or $* *$ $\mathrm{P}<0.01$ ( $t$-test)

inhibits IL-2 and IFN- $\gamma$ production and T-lymphocyte proliferation and is present in high concentrations in tick saliva (Bowman et al. 1996). $\mathrm{PGE}_{2}$ inhibits in vitro cytokine production by $\mathrm{T}_{\mathrm{H}} 1$ cells; however, it has no effect on $\mathrm{T}_{\mathrm{H}} 2$ cells. Up-regulation of IL-4 and IL-10 probably leads to the development of a $\mathrm{T}_{\mathrm{H}} 2$ response, 
resulting in a reduction of the $\mathrm{T}_{\mathrm{H}} 1$ response (Ramachandra and Wikel 1992, Wikel 1999, Kovář et al. 2001, Schoeler and Wikel 2001, Wikel and AlarconChaidez 2001).

Tick-mediated suppression of the $\mathrm{T}_{\mathrm{H}} 1$-lymphocyte reactivity may inhibit expansion of antigen specific $\mathrm{T}$ lymphocyte clones (IL-2), differentiation of B-lymphocytes (IL-4, IL-6, IL-13), activation of macrophages (IFN- $\gamma$ ), and natural killer cell activity (IL-12, IL-15, IFN- $\gamma$ ). The tick-induced $\mathrm{T}_{\mathrm{H}} 2$ cytokine profile seems to be advantageous for the survival of the tick because of the anti-inflammatory effect of $\mathrm{T}_{\mathrm{H}} 2$ cytokines. These anti-inflammatory mechanisms may also enhance the transmission of tick borne pathogens (Schoeler and Wikel 2001, Wikel and Alarcon-Chaidez 2001).

In our experiments, Rhipicephalus appendiculatus, Amblyomma variegatum and Ixodes ricinus SGE modulated proliferation of human peripheral blood T-lymphocytes in vitro in various ways, depending on feeding stage and sex. In majority of treatments, responses of lymphocytes to tick SGE when stimulated with mitogens simultaneously or $2 \mathrm{~h}$ after exposure to SGE showed no significant differences (Rolníková et al., unpublished results).

The suppressive effect of the $R$. appendiculatus SGE on the production of a number of cytokines (IFN- $\alpha$, IFN- $\gamma$, IL-1, IL-5, IL-6, IL-7 and IL-8) in human leucocytes has already been demonstrated (Fuchsberger et al. 1995). Kubeš et al. (2000) reported that salivary gland extracts derived from $A$. variegatum females decreased in vitro natural killer (NK) activity of healthy persons. Hajnická et al. (2001) showed that the A. variegatum SGE reduced the level of IL-8, resulting in inhibition of chemotaxis of neutrophils. As the SGE-induced recruitment of leucocytes provides a defence against a parasitic attack, the anti-IL- 8 activity may facilitate tick blood-feeding. Additionally, Kocáková et al. (2002) reported that $R$. appendiculatus and $A$. variegatum SGE reduced levels of both, IL- 8 and MIP- $1 \alpha$, a chemokine responsible for chemotaxis of human monocytes.

In general, in-vitro proliferative responses of mouse, human, or cattle lymphocytes to SGE of partially engorged female ticks were found to be suppressed (Bergman et al. 1995, Schoeler et al. 2000, Kováŕ et al. 2001, Turni et al. 2002), however, no data have been available on the effects of SGE derived from unfed female or male ixodid ticks. Sexual behaviour of some tick species evokes speculation about possible cooperation between sexes in the interaction with the host (Bior et al. 2002). The specific function of male R. appendiculatus ticks in female tick feeding has been reported (Wang et al. 1999). Rhipicephalus appendiculatus male ticks mate on the host with the feeding females, and then help their mates to complete successful engorgement by secreting immunosuppressive saliva components into the co-feeding site. Differences in male and female SGE protein profiles presented by Gašperík et al. (2000) demonstrated the existence of sexual dimorphisms in $R$. appendiculatus, Dermacentor reticulatus and $A$. variegatum. The support of female tick feeding by male SGE indicates different functions of saliva from both sexes and the effective cooperation between males and females during their feeding on the host. The different role of the sexes in host immunomodulation is also supported by our study, showing, in some cases, controversial responses of human lymphocytes to male and female SGE isolated from $R$. appendiculatus and $A$. variegatum, respectively. The strong stimulation of lymphocytes by 2 -day fed $R$. appendiculatus males is also very interesting. The results of different, sometimes quite opposite effects of male and female SGE on lymphocyte proliferation points to the importance of "cooperation" of sexes during their feeding on the host. The mechanism how female and male ixodid ticks modulate the immune response of their hosts needs to be studied in more detail.

Our experiments with SGE of I. ricinus females, derived from various stages of engorgement, showed their inhibitory effect on PHA- and ConA-induced proliferation of human peripheral blood T-lymphocytes. Very interesting is our finding on the strongest inhibitory effect of SGE of unfed I. ricinus females. The presence of immunosuppressive substances in unfed ticks is not surprising, as they have to counteract host defences as soon as they attach to their hosts. Also the expression of novel proteins during engorgement of hard ticks is well known, leading to production of a wide array of biologically active compounds in their salivary glands (Sonenshine 1991, Sauer et al. 1995). We treated human lymphocytes with certain concentrations of soluble SGE proteins (i.e. a cocktail of immunosuppressive as well as antigenic compounds). Based on our results we suppose that the ratio of immunosuppresive compounds in $I$. ricinus SGE changes during feeding, being probably lower in partially engorged ticks. Recently, Leboulle et al. (2002) have detected a novel protein - immunosuppressor (Iris) in the SGE of 5-day fed female $I$. ricinus. They found that expression of Iris was induced in the salivary glands of I. ricinus during the feeding process and that Iris was secreted into the tick saliva. It suppressed T-lymphocyte proliferation and induced a $\mathrm{T}_{\mathrm{H}} 2$ type immune response and inhibited the production of pro-inflammatory cytokines (IL-6 and TNF). Kovár et al. (2001) investigated the tick-mediated (I. ricinus SGE) modulation of human T-cell proliferation and cytokine synthesis using human peripheral blood mononuclear cells (PBMCs) stimulated with ConA or LPS. The SGE significantly inhibited the in vitro production of IL- 2 and IFN- $\gamma$. In contrast, the production of IL-4, IL-6, and IL-10 was significantly increased. In a subsequent study the authors showed that the SGE of partially engorged I. ricinus inhibited T-lymphocyte proliferation (Kováŕ et al. 2002). 
In general, our results confirmed the suppressive effect of the SGE from partially engorged female ixodid ticks tested on mitogen-stimulated human peripheral blood T-lymphocyte proliferation. In contrast to $I$. ricinus, stimulatory effect was observed in unfed and 2day fed $A$. variegatum females, while 9-day fed females strongly suppressed lymphocyte proliferation. We suggest that this is not the consequence of absence of immunosuppressive compounds in the saliva of unfed ticks, but more probably results from the abundance of compounds having no immunosuppressive properties.

In $R$. appendiculatus females and $A$. variegatum males, differences in responses of PHA- and ConA- stimulated lymphocytes have been found. These differences could result, in part, from different effects of SGE on various subsets of T-lymphocytes, as PHA stimulates preferentially $\mathrm{CD}^{+}$, while ConA stimulates more $\mathrm{CD} 8^{+}$ T-lymphocytes (e.g. Buc 2001). However, these questions should be addressed in subsequent studies dealing with effects of tick SGE on proliferation of various subsets of T-lymphocytes.

Acknowledgements. The research was financially supported by Evolutec Ltd. and partly by Grant VEGA, No. 2/1129/21, from the Slovak Academy of Sciences and Project APVT-51004702. The authors wish to thank V. Taragel'ová for screening tick samples by PCR.

\section{REFERENCES}

BERGMAN D.K., RAMACHANDRA R.N., WIKEL S.K. 1995: Dermacentor andersoni: salivary gland proteins suppressing T-lymphocyte responses to Concanavalin A in vitro. Exp. Parasitol. 81: 262-271.

BIOR A.D., ESSENBERG R.C., SAUER J.R. 2002: Comparison of differentially expressed genes in the salivary glands of male ticks, Amblyomma americanum and Dermacentor andersoni. Insect Biochem. Mol. Biol. 32: 645-655.

BOWMAN A.S., DILLWITH J.W., SAUER J.R. 1996: Tick salivary prostaglandins: presence, origin and significance. Parasitol. Today 12: 388-395.

BRADFORD M.M. 1976: A rapid and sensitive method for the quantitation of microgram quantities of protein utilizing the principle of protein-dye binding. Anal. Biochem. 72: $248-254$.

BROSSARD M., WIKEL S.K. 1997: Immunology of interactions between ticks and hosts. Med. Vet. Entomol. 11: 270-276.

BUC M. 2001: Imunológia. Veda, Bratislava, 454 pp.

FERREIRA B.R., SILVA J.S. 1999: Successive tick infestations selectively promote a T-helper 2 cytokine profile in mice. Immunology 96: 434-439.

FUCHSBERGER N., KITA M., HAJNICKÁ V., IMANISHI J., LABUDA M., NUTTALL P.A. 1995: Ixodid tick salivary gland extracts inhibit production of lipopolysaccharide-induced mRNA of several different human cytokines. Exp. Appl. Acarol. 19: 671-676.

GAŠPERÍK J., KOCÁKOVÁ P., SLOVÁK M., HAJNICKÁ V., FUCHSBERGER N., NUTTALL P.A. 2000: Differences in salivary gland extracts derived from male and/or female ticks. In: M. Kazimírová, M. Labuda and P.A. Nuttall (Eds.), Proceedings of the $3^{\text {rd }}$ International Conference "Ticks and Tick-borne Pathogens: Into the $21^{\text {st }}$ Century". Slovak Academy of Sciences, Bratislava, pp. 177-179.

GILLESPIE R.D., DOLAN M.C., PIESMAN J., TITUS R.G. 2001: Identification of an IL-2 binding protein in the saliva of the Lyme disease vector tick, Ixodes scapularis. J. Immunol. 166: 4319-4327.

GILLESPIE R.D., MBOW M.L., TITUS R.G. 2000: The immunomodulatory factors of bloodfeeding arthropod saliva. Parasite Immunol. 22: 319-331.
HAJNICKÁ V., KOCÁKOVÁ P., SLÁVIKOVÁ M., SLOVÁK M., GAŠPERÍK J., FUCHSBERGER N., NUTTALL P.A. 2001: Anti-interleukin-8 activity of tick salivary gland extracts. Parasite Immunol. 23: 483-489.

KOCÁKOVÁ P., HAJNICKÁ V., SLÁVIKOVÁ M., SLOVÁK M., GAŠPERÍK J., VANČOVÁ I., FUCHSBERGER N., NUTTALL P.A. 2002: Anti-chemokine activity of tick salivary gland extracts. In: $4^{\text {th }}$ International Conference on Ticks and Tick-Borne Pathogens, 21-26 July 2002, The Banff Centre, Banff, Alberta, Canada, Program and Abstracts, p. 94.

KOPECKÝ J., KUTHEJLOVÁ M. 1998: Suppressive effects of Ixodes ricinus salivary gland extract on mechanisms of natural immunity in vitro. Parasite Immunol. 20: 169-174.

KOVÁŘ L., KOPECKÝ J., ŘÍHOVÁ B. 2001: Salivary gland extract from Ixodes ricinus tick polarizes the cytokine profile toward $\mathrm{Th} 2$ and suppresses proliferation of $\mathrm{T}$ lymphocytes in human PBMC culture. J. Parasitol. 87: 1342-1348.

KOVÁŘ L., KOPECKÝ J., ŘÍHOVÁ B. 2002: Salivary gland extract from Ixodes ricinus tick modulates the host immune response towards the Th2 cytokine profile. Parasitol. Res. 88: 1066-1072.

KUBEŠ M., FUCHSBERGER N., LABUDA M., ŽUFFOVÁ E., NUTTALL P.A. 1994: Salivary gland extracts of partially fed Dermacentor reticulatus ticks decrease natural killer cell activity in vitro. Immunology 82: 113-116.

KUBEŠ M., KOCÁKOVÁ P., SLOVÁK M., FUCHSBERGER N., NUTTALL P.A. 2000: Salivary gland extracts of different partially fed ticks affects human natural killer cell activity in different manner. In: M. Kazimírová, M. Labuda and P.A. Nuttall (Eds.), Proceedings of the $3^{\text {rd }}$ International Conference "Ticks and Tick-borne Pathogens: Into the $21^{\text {st }}$ Century". Slovak Academy of Sciences, Bratislava, pp. 173-176.

KUBEŠ M., KOCÁKOVÁ P., SLOVÁK M., SLÁVIKOVÁ M., FUCHSBERGER N., NUTTALL P.A. 2002: Heterogeneity in the effect of different ixodid tick species on human natural killer cell activity. Parasite Immunol. 24: 23-28.

KUTHEJLOVÁ M., KOPECKÝ J., ŠTĚPÁNOVÁ G., MACELA A. 2001: Tick salivary gland extract inhibits 
killing of Borrelia afzelii spirochetes by mouse macrophages. Infect. Immun. 69: 575-578.

LEBOULLE G., CRIPPA M., DECREM Y., MEJRI N., BROSSARD M., BOLLEN A., GODFROID E. 2002: Characterization of a novel salivary immunosuppressive protein from Ixodes ricinus ticks. J. Biol. Chem. 277: 10083-10089.

RAMACHANDRA R.N., WIKEL S.K. 1992: Modulation of host-immune responses by ticks (Acari: Ixodidae): effects of salivary gland extracts on host macrophages and lymphocyte cytokine production. J. Med. Entomol. 5: 818-826.

RIBEIRO J.M.C. 1995a: How ticks make a living. Parasitol. Today 11: 91-93.

RIBEIRO J.M.C. 1995b: Blood-feeding arthropods: live syringes or invertebrate pharmacologists? Infect. Agents Dis. 4: $143-152$.

RIBEIRO J.M.C., FRANCISCHETTI I.M.B. 2003: Role of arthropod saliva in blood feeding: sialome and postsialome perspectives. Annu. Rev. Entomol. 48: 73-88.

ROLNÍKOVÁ T., KAZIMÍROVÁ M., BUC M. 2002: Proliferačné odpovede l'udských periférnych krvných lymfocytov na extrakty slinných žliaz kliešt’a Amblyomma variegatum (Acari: Ixodidae). Alergie 4, Suppl. 3: 90.

SAUER J.R., McSWAIN J.L., BOWMAN A.S., ESSENBERG R.C. 1995: Tick salivary gland physiology. Annu. Rev. Entomol. 40: 245-267.

SCHOELER G.B., BERGMAN D.K., MANWEILER S.K. WIKEL S.K. 2000: Influence of soluble proteins from the salivary glands of ixodid ticks on in-vitro proliferative responses of lymphocytes from $\mathrm{BALB} / \mathrm{c}$ and $\mathrm{C} 3 \mathrm{H} / \mathrm{HeN}$ mice. Ann. Trop. Med. Parasitol. 94: 507-518.

SCHOELER G.B., WIKEL S.K. 2001: Modulation of host immunity by haematophagous arthropods. Ann. Trop. Med. Parasitol. 95: 755-771.

SONENSHINE D.E. 1991: Biology of Ticks. Vol. I. Oxford University Press, New York - Oxford, $447 \mathrm{pp}$.

TURNI C., LEE R.P., JACKSON L.A. 2002: Effect of salivary gland extracts from the tick, Boophilus microplus, on leucocytes from Brahman and Hereford cattle. Parasite Immunol. 24: 355-361.

WANG H., HENBEST P.J., NUTTALL P.A. 1999: Successful interrupted feeding of adult Rhipicephalus appendiculatus (Ixodidae) is accompanied by reprogramming of salivary gland protein expression. Parasitology 119: 143149.

WIKEL S.K. 1999: Modulation of the host immune system by ectoparasitic arthropods. Blood-feeding and tissue-dwelling arthropods manipulate host defenses to their advantage. Bioscience 49: 311-320.

WIKEL S.K., ALARCON-CHAIDEZ F.J. 2001: Progress toward molecular characterization of ectoparasite modulation of host immunity. Vet. Parasitol. 101: 275-287.

WIKEL S.K., BERGMAN D. 1997: Tick-host immunology: significant advances and challenging opportunities. Parasitol. Today 13: 383-389.

WILLADSEN P., JONGEJAN F. 1999: Immunology of the tick-host interaction and the control of ticks and tick-borne diseases. Parasitol. Today 15: 258-262. 